\title{
2011
}

Working Paper

(1)1

INSTITUTO DE POLÍTIGAS Y BIENES PÚBLIGOS [IPP]

\section{Spatial Patterns of ADOPTION OF JUST-IN-TIME MANUFACTURING}

\author{
AdelHeid Holl \\ CSIC - Institute of Public Goods And Policies (IPP) \\ RAfael Pardo \\ FUNDACIÓN BBVA \\ RUTH RAMA \\ CSIC - INSTITUTE OF ECONOMICS, GEOGRAPHY AND DEMOGRAPHY \\ (IEGD)




\section{INSTITUTO DE POLÍTICAS Y BIENES PÚBLICOS CCHS-CSIC}

Copyright (C2011. Holl, A., Pardo, R. \& Rama, R. All Rights reserved.

Do not quote or cite without permission from the author.

Instituto de Políticas y Bienes Públicos

Centro de Ciencias Humanas y Sociales

Consejo Superior de Investigaciones Científicas

C/ Albasanz, 26-28.

28037 Madrid (España)

Tel: +34916022300

Fax: +34 913045710

http://www.ipp.csic.es/

The working papers are produced by Spanish National Research Council - Institute of Public Goods and Policies and are to be circulated for discussion purposes only. Their contents should be considered to be preliminary. The papers are expected to be published in due course, in a revised form and should not be quoted without the authors' permission.

\section{How to quote or cite this document:}

Holl, A., Pardo, R. \& Rama, R. (2011). Spatial patterns of adoption of just-in-time manufacturing. Instituto de Políticas y Bienes Públicos (IPP), CCHS-CSIC, Working Paper, Number 1.

Available: http://hdl.handle.net/10261/32707 


\title{
SPATIAL PATTERNS OF ADOPTION OF JUST-IN-TIME MANUFACTURING ${ }^{1}$
}

\author{
ADELHEID HOLL \\ CSIC - Institute of PUblic GoOds and Policies (IPP-CCHS) \\ ADELHEID.HOLL@CCHS.CSIC.ES
}

\author{
Rafael Pardo \\ FUNDACIÓN BBVA \\ RPARDO@STANFORD.EDU
}

\section{RUTH RAMA \\ CSIC - INSTITUTE OF ECONOMICS, GEOGRAPHY AND DEMOGRAPHY (IEGD-CCHS) RUTH.RAMA@CCHS.CSIC.ES}

\begin{abstract}
:
In this paper we study the spatial pattern of Just-in-Time (JIT) adoption for a sample of medium-sized and large Spanish manufacturing firms. The recent literature has shown that location plays a significant role in the adoption of advanced technologies. We argue that the particular role location characteristics play for technology adoption depends on the type of technology. JIT differs from other advanced manufacturing technologies because it relates directly to the spatial coordination of a firms' internal production organisation with its external productive environment and depends on the quality of the transport system. Our results confirm the distinctive role of location for JIT adoption even after controlling for industry and plant-specific differences. We find that JIT adoption is greater in smaller cities but with higher accessibility indicating that urban congestion in larger urban areas likely reduces the benefits that firms may obtain from JIT implementation.
\end{abstract}

\section{CONTENTS}

1. INTRODUCTION

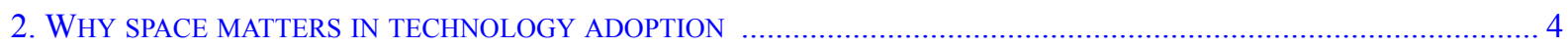

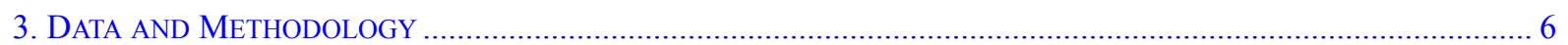

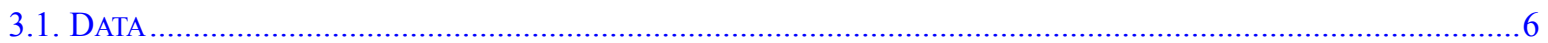

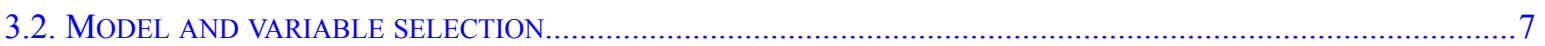

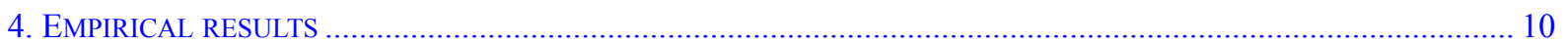

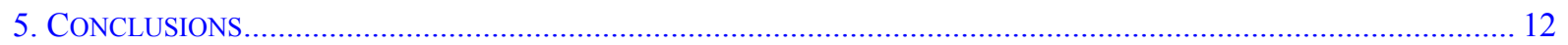

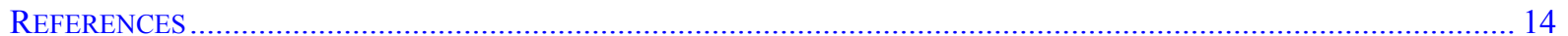

1 Financial support from the Spanish Ministerio de Ciencia e Innovación [ECO2010-17485], CSIC [200910I105] and Fundación BBVA is gratefully acknowledged. 


\section{INTRODUCTION}

The economic impact of new knowledge and innovations depends on its diffusion and use which are the driving forces behind technological change and economic growth. There is now wide agreement that the implementation of new technologies together with new forms of work organisation and management play a key role for firms to stay competitive. Empirical studies have, for example, shown how performance and productivity are related to the introduction of new technologies (Hitt, 1999; Brynjolfsson and Hitt, 2003; Bartel et al., 2007; Griffith, 2007; and see, Nakamura et al., 1998; Callen et al., 2000; Fullerton and McWatters, 2001; and Mackelprang and Nair, 2010, for the performance benefits of JIT implementation).

Just-in-time (JIT) is a manufacturing and inventory management technique, initially developed by the Toyota Motor Corporation in the 1950s. The JIT manufacturing system "originally referred to the production of goods to meet the customer demand exactly, in time, quality and quantity" now means producing with minimum waste of time and resources. The implementation of JIT manufacturing includes new practices such as better quality control, eliminating waste for waiting time or product defects, cleanliness and organisation, a multi-skilled workforce, and smoothing the flow of products through the factory and with suppliers and clients. The JIT policy is based on minimizing stock holdings and maximizing and co-ordinating inter- and intra-firm transactions with the production process. A key characteristic of JIT is the factor time and a focus on shorter lead times in production and delivery times. JIT, thus, relies on fast, frequent and reliable deliveries and communication to keep the scheduling of component deliveries tight (Allen et al., 1994).

With the increasing fragmentation of production and the increased role of the value of time for competitiveness in modern production systems, JIT has become an important technology in organising and locating production to ensure flexibility, speed and reliability in the production and delivery of goods. Yet, very little is still known about how location is related to JIT adoption.

There is now a large body of literature that shows that technology adoption in general is not even across space (Griliches, 1957; Hägerstrand, 1965 and 1967; Case, 1992; Karlsson, 1995, Harrison et al., 1996; Kelly and Helper, 1999; Holloway et al., 2002). Location is argued to influence both the capacity to innovate as well as the diffusion and adoption of innovations. Not all areas have the same ability to capture new technologies. First, learning about new technologies may differ across space. Geographical proximity may foster the transfer of technological knowledge and reduce uncertainties and the cost of technology adoption in agglomerations or larger markets where firms have greater opportunities to learn form the experience of prior adopters. It may also increase the probability of finding suitable suppliers of new technologies and it may provide firms with a wider variety of skills that facilitate the implementation. Second, how useful the adoption of a new technology is (the benefits a firm may derive in the future) also depends on spatial characteristics. Third, the size of local markets is related to technology adoption through the level of competition that firms face (Desmet and 
Parente, 2010). Greater competition in larger markets leads to larger firms that are consequently better able to absorb the fixed costs of technology adoption.

The majority of more recent micro-economic empirical studies analyzing factors related to technology adoption has focused on information and communication technologies (ICT) and what has been become known as the industrial digital divide (Gasper and Glaeser, 1998; Kolko, 2000; Galliano and Roux, 2004; Forman et al., 2005a; Forman et al., 2005b). These studies provide empirical support that ICT adoption is greater in larger markets.

Recent micro-level studies that have focused specifically on the adoption of advanced information technology related to the production process such as Computer Aided Design (CAD), Computer Numerically Controlled machinery (CNC) and robotics (Åstebro, 2004, Gómez and Vargas, 2008; Barbosa and Faria, 2008) have largely ignored spatial differences in adoption. In contrast, spatial technology diffusion among manufacturing firms attracted interest in earlier studies in the field of industrial geography (Camagni, 1985). Recent exceptions are Kelly and Helper (1996) and No (2008). Kelly and Helper (1996) find that the adoption of computer numerically controlled (CNC) machines is positively related to industry concentration. No (2008) finds for Canadian manufacturing firms that adoption of advanced manufacturing technologies is more likely in locations with more prior adopters.

JIT differs from other advanced manufacturing technologies because it relates directly to the coordination of a firms' internal production organisation with its external productive environment and depends on the quality of the transport system. Because JIT requires efficient, fast, and reliable transport, the benefits of JIT implementation relate directly to the spatial context. Few studies, however, have analysed JIT adoption. Gale (1999) studies the spatial patterns of JIT adoption among U.S. manufacturing establishments and finds no significant relation to nonmetropolitan location or miles of interstate highways in the establishment's county. Burmeister (2000) argues for France that JIT implementation is not correlated with the firms' accessibility in terms of transportation.

This paper makes a significant contribution to the literature on technology adoption. To the best of our knowledge, it is the first paper that shows that the spatial pattern of JIT adoption differs from other advanced manufacturing technologies. The differences can be explained precisely because JIT is an explicitly spatial technology that is placing increasing demands on the transport system.

\section{WHY SPACE MATTERS IN TECHNOLOGY ADOPTION}

Different models have been applied in the literature to explain technology adoption and diffusion. ${ }^{2}$ Most of these models focus either on learning about new technologies as determinant for adoption or on the anticipated costs and benefits associated with the adoption.

2 Diffusion and adoption refer to different levels of analysis of the same phenomenon: macro versus micro. Our research is at the micro-level and thus on adoption. 
First, the learning or epidemic model (Mansfield, 1968) assumes that adoption depends primarily on the incidence of learning about the new technology (Hägerstrand, 1965, 1967). Learning is related to personal contact which is facilitated with proximity. Thus, location plays a role because firms tend to learn about a new technology from neighbouring firms. In this approach, having a greater number of firms that have already adopted the technology nearby therefore raises the probability of adoption for other firms. In contrast, distance is regarded as a barrier to the spread of information (Hägerstrand, 1965). Hägerstrand moreover argued that technology diffusion follows the spatial hierarchy; that is new technologies are first adopted in large cities and urban agglomerations and only later on in more remote and smaller towns.

Second, adopting a new technology can be viewed as kind of investment under uncertainty. The decision to adopt is the result of a comparison of the future benefits of adopting the new technology with the costs of adopting it. Benefits are usually flow benefits obtained over the life span of the new technology. Costs are typically incurred at the time of adoption and are to a great degree sunk. Costs also include the opportunity cost of delay. However, under an option value approach, waiting also improves investor's chances of making the correct decision.

Third, Desmet and Parente (2010) show how competition facilitates technology adoption. Through the price elasticity of demand, larger markets lead to tougher competition and this facilitates the adoption of more advanced technologies. Firms in larger markets face greater substitution between goods and lower mark-ups. To break even, these firms must sell more goods; thus become large and better able to absorb the fixed costs of advanced technology adoption.

Firms adopt a new technology when their valuation is greater than the cost. For JIT, the benefits of implementation are likely related to the economic environment of the establishment. With JIT, location matters because time matters and the successful adoption of JIT depends on efficient, fast, and reliable transport between the factory and its suppliers and clients.

However, the specific role of space is most likely dependent upon the technology under examination. Similar spatial aspects may have different effects on the adoption of different types of technology. Griliches (1957) seminal paper on hybrid corn adoption across US states showed that adoption was a function of differences in hybrid productivity, dependent itself on the adaptability of a particular hybrid to the specific characteristics of the area.

In their literature review, Lissoni and Metcalf (1994) notice that patterns of adoption of similar technologies are comparable in similar geographic locations (Lissoni and Metcalfe, 1994). Most of the empirical literature on technology adoption has, however, not looked at how the role of space is dependent upon the technology under examination. Two recent exceptions are Luque (2002) and Foreman et al. (2005). Luque (2002) finds that market concentration shows a different effect on laser technology than on computer numerically controlled machine tools (CNC) adoption. Forman et al. (2005c) show for ICT adoption that technologies that involve communication across establishments show a greater adoption rate in rural areas. However, 
frontier technologies for communication within establishments are adopted to a greater extent in urban areas.

For JIT, market size may have two contrasting effects on adoption. On the one side, greater local markets foster the circulation of information and increases competition. This should induce greater adoption in larger markets. On the other side, firms in larger markets face greater congestion in the transport system. JIT is an advanced manufacturing technology with an explicit spatial dimension linking the factory to suppliers and clients. For its successful implementation, efficient, fast, and reliable transport is crucial. Greater congestion in larger markets could therefore deter firms from implementing JIT. We expect this second type of effect to be more relevant for JIT adoption compared to the adoption of other advanced manufacturing technologies that are limited to the inside of the factory.

\section{Data And Methodology}

\subsection{Data}

The data employed in the following analysis were obtained from a company-level survey targeting firms in manufacturing industry and conducted in 2003. The sample provides information on 1031 companies. All the companies had 50 or more employees. In order to establish the dimension of the population of plants in terms of sector, region and size, we used the information provided by the Directorio Central de Empresas (DIRCE) from the National Institute of Statistics. The regional distribution of plants was taken into account. Sectors were defined according to the CNAE classification (National Classification of Economic Activities), similar to the European NACE rev1. We selected companies for analysis from the Dun \& Bradstreet Spain list. The sampling process was made by quotas by company size (50-99 employees, 100-499 and more than 500) and regions (17 Autonomous Regions); and quotas by company size and industries. The survey includes all the Spanish manufacturing industry (26 industries). Given their size, sector and geographic location, the sampled firms are statistically representative of firms with over 50 employees in the above mentioned Spanish industries. For a confidence level of $95.5 \%$, the sampling error is $\pm 2.8 \%$. A pre-test was conducted. At the company level, in most cases we interviewed Production Directors, each personal interview lasting approximately one hour. The survey is not hampered by significant item non-response.

Some of the questions follow an ordinal 1-10 Likert scale, indicating the interviewee's assessment (Appendix 1). In contrast to variables which capture objective and quantitative information, it is well known that subjective evaluations may contain a greater degree of error. On the other hand, such variables are sufficiently robust and allow valuable dimensions of a factor, which would otherwise remain concealed, to be captured. Moreover, assessments and evaluations are a basic facet of organisational life. 


\subsection{Model and variable selection}

Adoption of a new technology occurs if (1) the establishment learns about the innovation, and (2) the anticipated benefits of adopting exceed the costs. However, we do not observe the net value to establishments of adoption. This is our latent endogenous variable. We observe only discrete choices of adoption or non-adoption of technology $\tau$.

Let adoption $y_{i \tau}$ of firm $i=1,2$, of technology $\tau$ be captured by a binary choice model

$$
y_{i \tau}=\left\{\begin{array}{c}
1 \text { if } y_{i \tau}^{*} \geq 0 \\
0 \text { else }
\end{array}\right.
$$

where the latent variable $y_{i \tau}^{*}$ representing firm $i$ 's underlying propensity to adopt the new technology $\tau$ is a linear function of observable firm specific characteristics $c_{i}$, industry characteristics $p_{i}$, and location characteristics $r_{i \tau}$ related to the municipality where the establishment is located

$$
y_{i}^{*}=c_{i} \beta_{1}+p_{i} \beta_{2}+r_{i \tau} \beta_{2}+v_{i}
$$

In order to test our hypothesis, that the effect of location is sensitive to the specificities of the new technology, we compare the adoption of JIT to the adoption of Computer Aided Design and Manufacturing (CAD/CAM). CAD is the use of computer technology for the process of design and design-documentation and CAM refers to computer assisted machinery control in production. It is an advanced manufacturing technology that unlike JIT only refers to firms' internal production organisation.

In the empirical implementation we assume first that the error terms of each establishment are normally distributed and independent across municipalities but potentially correlated within municipalities. Thus we estimate probit models with robust standard errors that are clustered by municipality. Second, the decision to adopt JIT and the decision to adopt CAD/CAM could be taken simultaneously. To capture the possible interdependence between the two choices, we estimate a bivariate probit model for the adoption of JIT and CAD/CAM. In this model the probit equations on JIT adoption and CAD/CAM adoption are estimated simultaneously. The model allows for the correlation of the error terms between the two adoption decisions. The correlation between the two error terms is estimated as an auxiliary parameter and simultaneity between the two decisions is captured by allowing a correlation between the unobserved variables influencing each decision. 


\section{Explanatory variables}

Firm and establishment level characteristics: The literature shows that specific company characteristics may affect firms' propensity to adopt new technologies. Firm size has been analysed in many studies on technology adoption and most studies find a positive relation between the likelihood of adoption and the size of the firm (see, for Cainarca et al 1990; (Lissoni and Metcalfe, 1994). More specifically, large plants are more likely to adopt most of the practices associated to JIT (e.g. cycle time reductions) (Shah and Ward, 2003). The reasons for their greater propensity of technology adoption is argued to be related to their greater human and capital resources and to their greater ability to spread the sunk cost of adoption over more sales (Åstebro 2004). As with firms size, firms that are part of a multinational company may have more financial resources available for adoption and they may be better able to reduce the risk of technology adoption. Moreover, some empirical studies have shown that the adoption of new technology may be associated to technology transfers undertaken by multinational enterprises (Hall, 2005). Finally, some authors argue that multi-unit companies, such as multinationals, are able to benefit simultaneously from different types of externalities in different locations; these spatial aspects may affect their patterns of technology adoption (Galliano et al., 2001). Multinationals, we claim, may set their main office in an urban area to benefit from agglomeration economies and an industrial plant in a less congested area to enjoy better road communications; this geographic structure of the company may encourage technology adoption. We further account for the origin of the foreign capital and the degree to which the firm sells in foreign markets. Exporters could be more likely to be early adopters of technology because they are exposed to greater competition and technology adoption can help those firms to stay competitive.

Outsourcing and small batch production. In addition, the characteristics of the production process may also be related to the adoption of new technologies. JIT is generally related to flexible production strategies. Flexible production organisation is also often associated with low-volume and customised production (D'Costa, 2004). We test if companies which define their type of production as small batch production are more likely to adopt JIT. Furthermore, outsourcing is related to a more fragmented production process. Such processes have greater and more complex requirements for coordination between clients and subcontractors production processes and in these cases the benefits from JIT adoption could be greater. At the same time, outsourcing can enable firms to save capital and labour resources in the outsourced processes which may then be used for the adoption of new technology. Subcontracting relationships also present a certain type of stable relationships where firms are bound by contract. Stability in relations can facilitate technology adoption as firms may be more likely to recover the costs of adoption. Geographical studies consider that subcontracting relationships, i.e. a networked organisation of the firm, may favour technology adoption because such relationships facilitate inter-firm flows of information (Lissoni and Metcalfe, 1994). Karshenas and Stoneman (1995) also consider that networks "provide a framework of reference within which to analyse 
information acquisition" (p. 273). In evolutionary models, adoption encompass organizational elements (Nelson, 1982). Consequently, the adoption of specific technology is not seen in isolation but rather in accordance with simultaneous changes in organisation.

Innovation and skills. The successful adoption of new technologies requires skills and learning potential of a plant's workforce. According to the literature, R\&D expenditures and the number of R\&D employees are positively associated to adoption (Karshenas and Stoneman, 1995) (Lissoni and Metcalfe, 1994). Firms that spend more on R\&D may be better able to assimilate new technology (Cohen and Levinthal, 1989). Karshenas and Stoneman (Karshenas and Stoneman, 1995) suggest that there may be complementarities between technology generation and technology adoption. We use information on product innovation to proxy the absorptive capacity of the establishment for new technologies. The presence of a skilled workforce may also positively influence technology adoption (Bartoloni and Baussola, 2001; Pianta, 2005). More specifically, a review of the JIT literature mentions high levels of training as a plant characteristic strongly related to JIT implementation (Mackelprang and Nair, 2010). We use information on the complexity of industrial tasks in the establishment to proxy the skill level of the workforce.

Industry: The likelihood to adopt a new manufacturing technology also depends on the industry sector in which the firm operates. Sectors vary to a large degree in their technological requirements as well as in the suitability of their specific production processes to a new technology. As for JIT, it was initially developed in the automotive industry, but is now also increasingly adopted in other sectors (Gale, 1999) e.g. the electronics industry (McCann and Fingleton 1996), the textile and apparel industry (Abernathy et al. 1999; Bruce et al. 2004) or the food sector (Bourlakis and Bourlakis, 2004). It is, thus important to control for industry characteristics because some industries will also tend to cluster in certain locations. Thus, differences in industry location patterns and industry adoption rates may partly explain differences in spatial adoption rates.

Space: The focus in our analysis lies on spatial variables and their relation to the adoption process. Geographic studies suggest that agglomerations may have some advantages with regard to diffusion because information circulates better in such areas thanks to their active social life and to subcontracting relationships among local companies (Lissoni and Metcalfe, 1994). According to early geographic studies published in the 1950s and 1960s, diffusion followed a sequence from major urban centres to minor centres (Lissoni and Metcalfe, 1994). Research in operations management considers that geographic location may influence the successful implementation of JIT (Mackelprang and Nair, 2010). Studies in the car industry provide evidence for the importance of highway access in ensuring punctual delivery in an environment of just-in-time production (Smith and Florida, 1994; Klier, 1999 and 2000).

From our survey data we know the municipality in which each establishment is located. This is a fine-grained location information given that there are approximately 8.000 municipalities in Spain with an average size of 62 square kilometres and an average population of somewhat 
over 5.000 inhabitants. ${ }^{3}$ With this information, we geo-reference all our establishments in the sample.

The theoretical and empirical literature has shown the influence of urban or densely populated location. We test a number of variables related to the location of the establishment such as population size, population density, and a number of dummy variables aimed to capture the more or less urban nature of the municipality where the establishment is located. The specific role of location for JIT, however, derives from its requirement of an efficient, fast, and reliable transport system. Thus, we expect variables that reflect location characteristics in relation to the transport system to play a stronger role for JIT adoption. Accessibility indicators are a widely used way to proxy location characteristics with relation to the transport system. Accessibility is the ease to overcome spatial separation. It defines the opportunities of exchange made available to people and firms through the transport system. Market access is important to understanding the potential for efficient JIT implementation. We use Geographic Information Systems (GIS) to calculate accessibility measures based on the 2003 Spanish mainland road network.

$$
a c c_{j}=p o p_{j}+\sum_{k \in L_{573}} \frac{p o p_{k}}{d_{k}}
$$

where $a c c_{j}$ is the accessibility of municipality $j$. The destination set L573 is defined as the 573 largest Spanish cities with more than 10,000 inhabitants. This covers over 75 percent of the total Spanish peninsular population. op $_{k}$ is measured in hundred thousands. $\mathrm{d}_{j k}$ is the distance between municipality $j$ and $k$ and is based on shortest path travel times along the real road network, measured in units of 30 minutes and where $d_{j k}=1$ for all municipalities that are less than half an hour travel time apart. See Holl (2007) for an illustration.

Appendix 1 provides a summary description of the survey variables and Appendix 2 shows the correlation matrix.

\section{EMPIRICAL RESULTS}

Table 1 shows the percentage of establishments in our sample using JIT and CAD/CAM respectively by the population size of the municipality where the establishment is located. ${ }^{4}$ For JIT, we see that the smallest percentage of JIT users occurs in larger cities with more than 125.000 inhabitants. In contrast, it is precisely in those areas where CAD/CAM adoption is highest.

3 Our analysis refers to mainland Spain only. We exclude establishments located in the islands because of the distinct role of location in these places.

4 The percentage of firms which have adopted JIT is in line with Huerta et al. (2003) who provide some quantification of JIT adoption in Spanish manufacturing firms. 
Table 2 provides mean differences tests of location characteristics for adopters and non-adopters of JIT and CAD/CAM. The difference between the mean municipality size of JIT adopters and non-adopters is not significant, but large urban areas show a slightly significant greater percentage of non-adopters. Adopters in contrast tend to locate in somewhat more densely populated areas but above all in areas with greater transport accessibility. For CAD/CAM we observe a significant difference between adopters and non-adopters only for the population size variables measured by the mean population and the percentage in large urban areas but not for density and accessibility. Consistent with the figures in Table 1, CAD/CAM adoption is greater in larger cities.

Table 3 presents the results from the probit estimation for JIT adoption. Overall, our findings suggest that JIT adoption is significantly related to location characteristics even after controlling for industry and firm-specific characteristics. Again, the significant variables are transport accessibility with a positive relation and the dummy variable for large urban areas with a negative sign. These results reflect that JIT may suffer the constraints related to urban location and requires good transport accessibility for its successful implementation. In column (1) to (4) we have introduced the location characteristics individually together with industry dummy variables and establishment characteristics for size, skills, foreign ownership, the percentage of EU foreign capital and the percentage of foreign sales. As for the establishment characteristics, JIT adopters tend to be larger establishments and with foreign ownership. However, multinational firms with a greater percentage of EU capital show a smaller propensity for JIT adoption compared to multinationals with greater capital participation from other regions. A possible explanation is that the group of non- EU multinationals include the subsidiaries of Japanese companies. These companies, pioneers in the use of such manufacturing system, may be more inclined to use JIT. However, this hypothesis could not be tested with our data. The percentage of foreign sales shows a slightly significant positive relation to JIT adoption, but significance disappears with the inclusion of the large urban area dummy. The proxy for the workforce skill level shows no significant relation to JIT adoption. In column (5) we introduce the dummy for large urban areas together with the accessibility measure. Results are qualitatively the same. In column (6) we add further establishment controls. Small batch production is negatively related to JIT adoption, whereas outsourcers and more innovative firms show a greater propensity for JIT adoption. Again, our results for the location characteristics remain robust to the inclusion of these further controls.

Table 4 presents the results from the probit estimation for CAD/CAM adoption. Consistent with the descriptive results of Table 2 we find that even after controlling for industry and firmspecific characteristics, the location characteristics significantly related to CAD/CAM adoption are municipality size and the dummy for large urban areas. Accessibility is only significant at the $10 \%$ level.. Large urban areas show higher CAD/CAM adoption and, as shown in Table 3, lower JIT adoption. There are also some differences for establishment characteristics. Now, the variable capturing the skill level of the workforce is positive and significant. Foreign ownership, 
in contrast, is not significantly related to $\mathrm{CAD} / \mathrm{CAM}$ adoption, nor does the origin of the foreign capital show a significant coefficient. However, the degree to which the establishment sells in foreign markets is more consistently related to CAD/CAM adoption. As with JIT, in column (5) we introduce the large urban area dummy together with the accessibility measure. The dummy for large urban areas remains positive and significant whereas accessibility shows again only a slightly significant relation with $\mathrm{CAD} / \mathrm{CAM}$ adoption and with the inclusion of further establishment controls in column (6), accessibility is no longer significant at conventional levels. However, the large urban area dummy shows a robust positive and significant relation to $\mathrm{CAD} / \mathrm{CAM}$ adoption.

So far we have treated the decisions to adopt JIT and the decision to adopt CAD/CAM as independent. Table 5 shows, however, a strong relation between JIT and CAD/CAM manufacturing. Out of the sample of firms that use JIT, 76.5\% also use CAD/CAM. In Table 6 we first repeat the separate probit estimations and include CAD/CAM as a further explanatory variable in the estimation of JIT adoption and JIT as a further explanatory variable in the estimation of CAD/CAM adoption. We see that adoption of either technology is positively related to the adoption of the other even after controlling for plant and industry characteristics. This indicates the joint nature of the decisions of adoption of JIT and CAD/CAM.

In Table 7 we allow for the possibility of joint decision on the adoption of JIT and CAD/ CAM. We present the results from the bivariate probit estimations for JIT and CAD/CAM adoption accounting for the potentially simultaneous nature of the two decisions. We present two specifications. Specification (1) only includes the large urban area dummy together with the industry and firm-specific controls and specification (2) includes in addition the accessibility measure. The ancillary parameter rho measures the correlation of the residuals from the two models. In both cases, the two equations are significantly associated, with rho $=0.26$ and significant at the $1 \%$ level and thus should be estimated jointly. The estimations confirm our prior findings. JIT is negatively related to city size over 125.000 inhabitants whereas CAD/CAM adoption is higher in those areas. Transport accessibility is positive and significant at the one percent level for JIT adoption but shows no significant relation to CAD/CAM adoption. Wald tests confirm that the coefficient estimates for these two location characteristics are significantly different for JIT adoption and CAD/CAM adoption. ${ }^{5}$

\section{Conclusions}

In an increasingly time-based competitive environment, JIT adoption plays an important role. We show that JIT adoption is related to the characteristics of the location of an establishment. Our findings show that JIT adoption is higher in areas with better transport accessibility and

$5 \quad$ As a further robustness test we have also carried out multinominal logit estimations where the options (1) only JIT adoption, (2) only CAD/CAM adoption, (3) JIT+CAD/CAM adoption are compared to the baseline of no adoption of these two technologies. Our main finding that urban size shows a negative relation to JIT adoption and a positive relation to $\mathrm{CAD} / \mathrm{CAM}$ adoption is confirmed. Results are available upon request. 
in smaller cities. A comparison with $\mathrm{CAD} / \mathrm{CAM}$ adoption offers evidence of a distinct role of location characteristics depending on the specific features of the new technology to be adopted. Our results indicate that urban congestion may reduce the benefits that firms may obtain from JIT implementation as congestion causes uncertainty in logistics operations.

This finding is consistent with recent studies that show the negative impacts of traffic congestion on supply chain organisation (Rao and Grenoble. 1991; McKinnon, 1999; McKinnon et al., 2008). These impacts are more pronounced in JIT production systems because JIT implies greater consequences of delays (Weisbrod and Fitzroy, 2008).

We provide empirical evidence on the differential role of space for the adoption of specific advanced manufacturing technologies. However, the analysis is limited in the sense that the estimations cannot prove causal relationships regarding technology adoption. Firms make decisions regarding technology adoption together with decision concerning a range of other company- and plant-level characteristics. With the survey data available in this study it is beyond the scope of the paper to control for all these factors as well as the simultaneous nature of many of these decisions.

Finally, the paper shows that complementing location variables traditionally used in the literature on technology adoption with GIS derived measure of accessibility provides new interesting insights through a more differentiated characterisation of the spatial patterns of technology adoption. 


\section{REFERENCES}

1. Abernathy, F.H., Dunlop, J.T., Hammond, J.H., D. Weil (1999) A Stitch in Time. Oxford University Press, New York

2. Allen B. J., Baumel C. P. and D. J. Forkenbrock (1994) Expanding the set of efficiency gains of a highway investment, Transportation Journal 34: 39-47.

3. Åstebro, T. (2004) Sunk costs and the depth and probability of technology adoption, Journal of Industrial Economics 52 (3):381-399.

4. Barbosa, N. and A.P. Faria (2008) Technology Adoption: Does Labour Skill Matter? Evidence from Portuguese Firm-level Data, Empirica, 35: 179-194

5. Bartel, A., Ichniowski, C., and K. Shaw (2007) How Does Information Technology Affect Productivity? Plant-Level Comparisons of Product Innovation, Process Improvement, and Worker Skills, Quarterly Journal of Economics 122 (4): 1721-1758.

6. Bartoloni, E., and M. Baussola (2001) The determinats of technology adoption in Italian manufacturing industries, Review of Industrial Organization 19: 305-328.

7. Belussi, F. (2005) Are Industrial Districts Formed by Networks Without Technologies? The Diffusion of Internet Applications in Three Italian Clusters, European Urban and Regional Studies 12:247-268.

8. Bourlakis, C., and M. Bourlakis (2004) The future of food supply chain management. In: Bourlakis, M., Weightman, P. (Eds.), Food Supply Chain Management. Blackwell, Oxford, pp. 221-230.

9. Bruce, M., Daly, L., N. Towers (2004) Lean or agile: A solution for supply chain management in the textiles and clothing industry? International Journal of Operations and Production Management 24 (2): 151-170.

10. Brynjolfsson E and L. Hitt (2003) Computing productivity: firm-level evidence. Review of Economics and Statistics 85:793-808.

11. Burmeister, A. (2000) Spatial dimensions of logistic strategies: a typology, in 3rd KFB Research Conference, Stockholm.

12. Cainarca, G. C., Colombo, M. G. and S. Mariotti (1990) Firm Size and the Adoption of Flexible Automation, Small Business Economics 2: 129-140.

13. Callen, J. L., C. Fader, and I. Krinsky (2000) Just-in-time: A cross-sectional plant analysis, Int. J. Production Economics 63: 277-301.

14. Camagni, R. P. (1985) Spatial diffusion of pervasive process innovation, Papers in Regional Science 58 (1): 83-95.

15. Cohen, W.M., and D.A. Levinthal (1989) Innovation and learning: The two faces of R\&D, Economic Journal 99: 569-596.

16. D'Costa, A. P. (2004) Flexible practices for mass production goals: economic governance in the Indian automobile industry. Industrial and Corporate Change, 13(2): 335-367.

17. Desmet, K. and S. L. Parente (2010) Bigger is better: market size, demand elasticity, and innovation, International Economic Review 51 (2): 319-333.

18. Forman, C., Goldfarb, A., and S. Greenstein (2005a) Geographic location and the diffusion of Internet technology, Electronic Commerce Research and Applications 4: 1-13.

19. Forman, C., Goldfarb, A., and S. Greenstein (2005b) How do industry features influence the role of location on internet adoption? Journal of the Association for Information Systems 6 (12): 383-408.

20. Forman, C, Goldfarb, A., and S. Greenstein (2005c) How Did Location Affect the Adoption of the Commercial Internet? Global Village vs. Urban Density, Journal of Urban Economics 58 (3): 389-420.

21. Fullerton, R. R. and C. S. McWatters (2001) The production performance benefits from JIT implementation, Journal of Operations Management 19: 81-96.

22. Fullerton, R.R., McWatters, C.S. and C., Fawson (2003) An examination of the relationships between JIT and financial performance, Journal of Operations Management 21: 383-404.

23. Gale, H. F. (1999) Adoption of Just-in-Time Manufacturing by Rural and Urban Plants, Review of Regional Studies 29 (2): 157-174. 
24. Gallander, S., and A. Larsson (2000) Outsourcing and location. in New Tracks on Sweedish Economic Reasearch in Europe. Mölle, Sweeden May 23-26.

25. Galliano, D., and P. Roux (2003) Spatial externalities, organisation of the firm and ICT adoption: the specificities of the French agri-food firm, Int. J. of Biotechnology 5:269-296.

26. Galliano, D., P. Roux, and M. Filippi (2001) Organisational and spatial determinants of ICT adoption: the case of French industrial firms, Environment and Planning A 33: 1643-1663.

27. Gasper, J. and E. L. Glaeser (1998) Information technology and the future of cities, Journal of Urban Economics 43 : 136-156.

28. Gómez Villascuerna, J. and P. Vargas Montoya (2008) Explaining the adoption of process technologies in Spanish manufacturing firms". Documentos de trabajo del Departamento de Economía y Empresa. Servicio de publicaciones de la Universidad de La Rioja.

29. Griffith, R. (2007) Technology, Productivity and Public Policy, Fiscal Studies 28 (3): 273-291.

30. Griliches, Z. (1957) Hybrid Corn: An exploration in the economics of technological change, Econometrica 25 (4): 501-522.

31. Hägerstrand, T. (1965) Aspects of the spatial structure of social communication and the diffusion of information, Papers in Regional Science 16 (1): 27-42.

32. Hägerstrand, T. (1967) Innovation Diffusion as a Spatial Process. Chicago: University of Chicago Press.

33. Hall, B.H. (2005) Innovation and diffusion. Pp. 459-484 in The Oxford Handbook of Innovation edited by J. Fagerberg, D.C. Mowery, and R.R. Nelson. New York: Oxford University Press.

34. Harrison, Bennett, M.R. Kelley and J. Gant (1996) Innovative Firm Behavior and Local Milieu: Exploring the Intersection of Agglomeration, Firm Effects, and Technological Change. Economic Geography. 72 (3): $233-258$.

35. Hitt L M, 1999) Information technology and firm boundaries: evidence from panel data" Information Systems Research 10(9) 134-149.

36. Holl, A. (2007) Twenty Years of Accessibility Improvements. The Case of the Spanish Motorway Building Programme. Journal of Transport Geography 15 (4): 286-297.

37. Holloway, G., Shankar, B., and S. Rahman (2002) Bayesian spatial probit estimation: a primer and an application to HYV rice adoption, Agric. Econ. 27: 383-402.

38. Huerta Arribas E, Bayo Moriones JA, García Olaverri C, J. Merino Díaz de Cerio (2003) Los desafíos de la competitividad. La innovación organizativa y tecnológica en la empresa española. Madrid: Fundación BBVA.

39. Karlsson, C. (1995) Innovation adoption, innovation networks and agglomeration economies, in: Technological Change, Economic Development and Space, edited by C.S. Bertuglia, M.M.Fisher and G.Petro, Springer, pp 184-206.

40. Karshenas, M., and P. Stoneman (1995) Technological diffusion. Pp. 265-297 in Handbook of the economics of innovation and technological change, edited by P. Stoneman. Oxford (UK) and Cambridge (USA): Blackwell.

41. Kelley, M. R. and S. Helper (1999) Firm size and capabilities, regional agglomeration, and the adoption of new technology. Economics of Innovation and New Technology 8 (1-2): 79-103.

42. Klier, T. H. (1999) Agglomeration in the U.S auto supplier industry, Economic Perspectives 23 (1): 18-34.

43. Klier, T. H. (2000) Does "Just-in-time" Mean "Right-next-door"? Evidence from the Auto Industry on the Spatial Concentration of Supplier Networks, Journal of Regional Analysis and Policy 30 (1): 41-57.

44. Kolko, J. (2000) The death of cities? The death of distance? Evidence from the geography of commercial Internet usage, in : I. Vogelsang and B.M. Compaine (eds) The Internet Upheaval, Cambridge MA : MIT Press, pp. 73-98.

45. Lissoni, F., and J.S. Metcalfe (1994) Diffusion of innovation ancient and modern: a review of main themes. in The Handbook of Industrial Innovation, edited by M. Dodgson and R. Rothwell. Cheltenham (UK) and Brookfields (US): Edward Elgar.

46. Luque, A. (2002) An Option-Value Approach To Technology Adoption In U.S. Manufacturing: Evidence From Microdata, Economics of Innovation and New Technology 11 (6): 543-568. 
47. Mackelprang, A.W., and A. Nair (2010) Relationship between just-in-time manufacturing practices and performance: A meta-analytic investigation, Journal of Operations Management 28: 283-302.

48. Mansfield, E. (1968) Industrial Research and Technological Innovation. New York: Norton.

49. McCann, P. and B. Fingleton (1996) The regional agglomeration impact of Just-In-Time input linkages: Evidence from the Scottish electronics industry, Scottish Journal of Political Economy 43 (5): 493-518.

50. McKinnon, A. (1999) The effect of traffic congestion on the efficiency of logistical operations. International Journal of Logistics: Research and Applications 2 (2): 111-129.

51. McKinnon, A., Edwards, J., Piecky, M., A. Palmer (2008) Traffic congestion, reliability and logistical performance: a multi-sectoral assessment, Tech. Rep., Logistics Research Centre, Heriot-Watt University, Edinburgh.

52. Nakamura, M., S. Sakakibara, and R. Schroeder (1998) Adoption of Just-in-Time Manufacturing Methods at U.S.- and Japanese-Owned Plants: Some Empirical Evidence, Transactions on Engineering Management 45 (3): $230-240$.

53. Nelson, R. and S. Winter (1982) An evolutionary theory of economic change. Cambridge. MA: Harvad University Press.

54. No, Joung Yeo A. (2008) Cities and Growth: Knowledge Spillovers in the adoption of advanced manufacturing technologies. The Canadian Economy in Transition Series 018.

55. Pianta, M. (2005) Innovation and employment. Pp. 568-598 in The Oxford handbook of innovation, edited by J. Fagerberg, D.C. Mowery, and R.R. Nelson: Oxford University Press.

56. Rao, K., Grenoble IV., W.L. (1991) Modelling the effects of traffic congestion on JIT. International Journal of Physical Distribution and Logistics Management 21 (2): 3-9.

57. Shah, R., and P.T. Ward (2003) Lean manufacturing: context, practice bundles, and performance, Journal of Operations Management 21:129-149.

58. Smith D.F. and R. Florida (1994) Agglomeration and Industrial Location: An Econometric Analysis of Japanese-Affiliated Manufacturing Establishments in Automotive-Related Industries, Journal of Urban Economics 36: 23-41.

59. Weisbrod, G. and S. Fitzroy (2008) Defining the Range of Urban Congestion Impacts on Freight and their Consequences for Business Activity, Presentation at the TRB Annual Conference, Washington, D.C.,January 2008. 
Table 1. Average adoption of JIT and CAD/CAM by municipality population size

\begin{tabular}{lll}
\hline & JIT & CAD/CAM \\
\hline Rural area: $<10.000$ & $31.7 \%$ & $45.6 \%$ \\
Small urban area: $10.000-<50.000$ & $33.1 \%$ & $42.0 \%$ \\
Intermediate urban area: $50.000-<125.000$ & $33.1 \%$ & $40.9 \%$ \\
Large urban area: 125.000 and more & $27.8 \%$ & $49.9 \%$ \\
\hline Source: Authors' own calculations using INE municipality population data & & \\
\hline
\end{tabular}




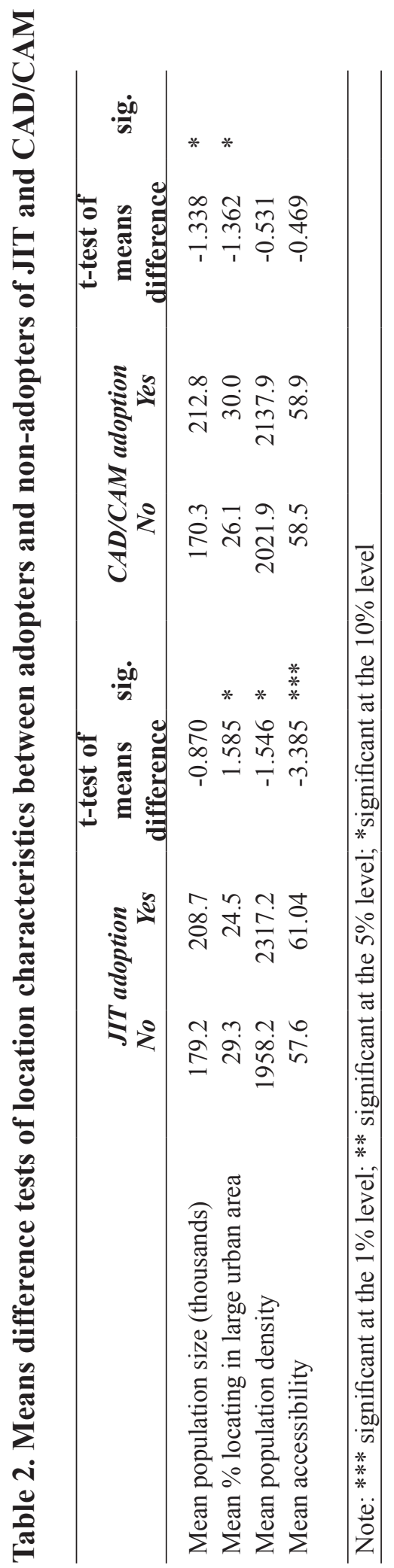


Table 3: Probit estimations of JIT adoption

\begin{tabular}{|c|c|c|c|c|c|c|}
\hline & (1) & (2) & (3) & (4) & (5) & (6) \\
\hline \multicolumn{7}{|l|}{ Location characteristics } \\
\hline Municipality size & $\begin{array}{l}-0.001 \\
(0.006)\end{array}$ & & & & & \\
\hline $\begin{array}{l}\text { Municipality population density } \\
\text { (in thousands) }\end{array}$ & & $\begin{array}{c}0.005 \\
(0.012)\end{array}$ & & & & \\
\hline Large urban area dummy & & & $\begin{array}{l}-0.202^{*} \\
(0.115)\end{array}$ & & $\begin{array}{l}-0.234^{* *} \\
(0.109)\end{array}$ & $\begin{array}{l}-0.280 * * * \\
(0.115)\end{array}$ \\
\hline Accessibility & & & & $\begin{array}{l}0.006^{* *} \\
(0.003)\end{array}$ & $\begin{array}{l}0.007 * * \\
(0.003)\end{array}$ & $\begin{array}{l}0.008 * * * \\
(0.003)\end{array}$ \\
\hline \multicolumn{7}{|l|}{ Plant Characteristics } \\
\hline Size (number of employees) & $\begin{array}{l}0.001 * * * \\
(0.0004)\end{array}$ & $\begin{array}{l}0.001 * * * \\
(0.0004)\end{array}$ & $\begin{array}{l}0.001 * * * \\
(0.0004)\end{array}$ & $\begin{array}{l}0.001 * * * \\
(0.0004)\end{array}$ & $\begin{array}{l}0.001 * * * \\
(0.0004)\end{array}$ & $\begin{array}{l}0.001 * * * \\
(0.0004)\end{array}$ \\
\hline Skill & $\begin{array}{c}0.011 \\
(0.017)\end{array}$ & $\begin{array}{l}0.011 \\
(0.017)\end{array}$ & $\begin{array}{r}0.009 \\
(0.017)\end{array}$ & $\begin{array}{c}0.013 \\
(0.017)\end{array}$ & $\begin{array}{l}0.011 \\
((0.017)\end{array}$ & $\begin{array}{l}0.007 \\
(0.018)\end{array}$ \\
\hline Foreign ownership & $\begin{array}{l}0.569 * * * \\
(0.161)\end{array}$ & $\begin{array}{l}0.562 * * * \\
(0.161)\end{array}$ & $\begin{array}{l}0.558 * * * \\
(0.161)\end{array}$ & $\begin{array}{l}0.544 * * * \\
(0.162)\end{array}$ & $\begin{array}{l}0.544 * * * \\
(0.162)\end{array}$ & $\begin{array}{l}0.564 * * * \\
(0.171)\end{array}$ \\
\hline$\%$ of EU foreign capital & $\begin{array}{l}-0.006 * * * \\
(0.002)\end{array}$ & $\begin{array}{l}-0.006 * * * \\
(0.002)\end{array}$ & $\begin{array}{l}-0.005 * * * \\
(0.002)\end{array}$ & $\begin{array}{l}-0.006 * * * \\
(0.002)\end{array}$ & $\begin{array}{l}-0.005 * * * \\
(0.002)\end{array}$ & $\begin{array}{l}-0.006 * * * \\
(0.002)\end{array}$ \\
\hline $\begin{array}{l}\% \text { of sales in international } \\
\text { markets }\end{array}$ & $\begin{array}{c}0.003^{*} \\
(0.0015)\end{array}$ & $\begin{array}{c}0.003 * \\
(0.0015)\end{array}$ & $\begin{array}{l}0.002 \\
(0.0016)\end{array}$ & $\begin{array}{c}0.003^{*} \\
(0.0015)\end{array}$ & $\begin{array}{l}0.002 \\
(0.0016)\end{array}$ & $\begin{array}{l}0.002 \\
(0.0016)\end{array}$ \\
\hline Small batch production & & & & & & $\begin{array}{l}-0.180 * * \\
(0.097)\end{array}$ \\
\hline Outsourcing & & & & & & $\begin{array}{r}0.183^{*} \\
(0.112)\end{array}$ \\
\hline Product innovation & & & & & & $\begin{array}{l}0.337 * * * \\
(0.101)\end{array}$ \\
\hline No. of observations & 932 & 932 & 932 & 932 & 932 & 904 \\
\hline Log likelihood & -534.2 & -534.1 & -533.9 & -532.1 & -529.7 & -498.6 \\
\hline Pseudo $\mathrm{R}^{2}$ & 0.079 & 0.080 & 0.082 & 0.083 & 0.087 & 0.111 \\
\hline \multicolumn{7}{|c|}{$\begin{array}{l}\text { Note: } * * * \text { denotes significance at the } 1 \% \text { level, } * * \text { the } 5 \% \text { level, and } * \text { the } 10 \% \text { level. Robust standard errors } \\
\text { corrected for clustering at the municipality level are reported in parenthesis. All estimations include } 22 \text { industry } \\
\text { sector dummies. }\end{array}$} \\
\hline
\end{tabular}


Table 4: Probit estimations of CAD/CAM adoption

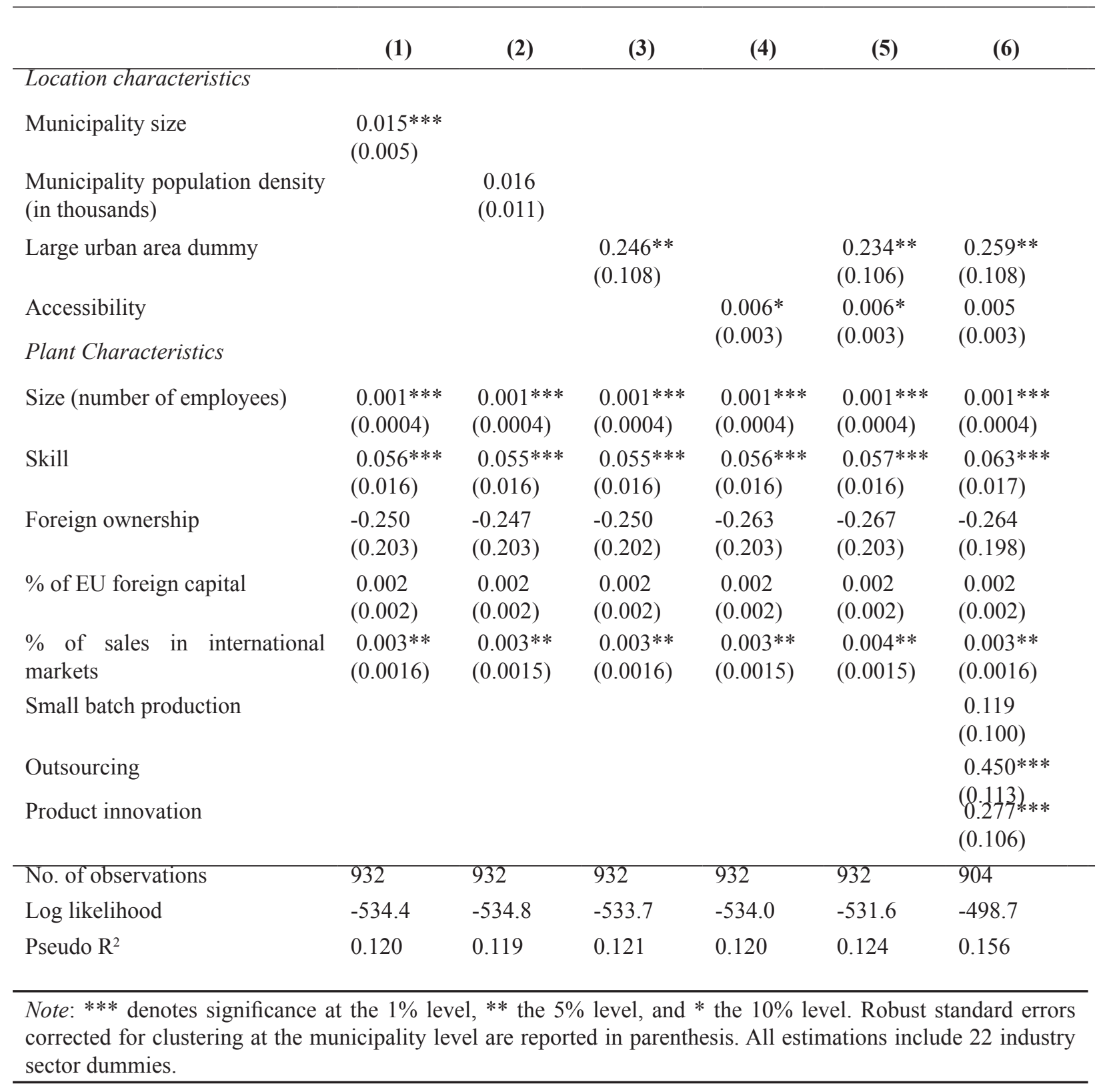


Table 5. Contingency table: JIT and CAD/CAM adoption

\begin{tabular}{|c|c|c|c|}
\hline $\begin{array}{l}\text { Count } \\
\text { Row }(\%) \\
\text { Column }(\%)\end{array}$ & $\begin{array}{l}\text { No CAD/CAM } \\
\text { production }\end{array}$ & $\begin{array}{l}\text { CAD/CAM } \\
\text { production }\end{array}$ & $\begin{array}{l}\text { Row } \\
\text { total }\end{array}$ \\
\hline No JIT production & $\begin{array}{l}283 \\
40.8 \\
79.1\end{array}$ & $\begin{array}{l}411 \\
59.2 \\
62.8\end{array}$ & $\begin{array}{l}694 \\
100 \\
68.5\end{array}$ \\
\hline JIT production & $\begin{array}{l}75 \\
23.5 \\
20.1\end{array}$ & $\begin{array}{l}244 \\
76.5 \\
37.3\end{array}$ & $\begin{array}{l}319 \\
100 \\
31.5\end{array}$ \\
\hline Column total & $\begin{array}{l}358 \\
35.3 \\
100 \\
\end{array}$ & $\begin{array}{l}655 \\
64.7 \\
100 \\
\end{array}$ & $\begin{array}{l}130 \\
100 \\
100 \\
\end{array}$ \\
\hline Pearson chi-square: $28.515 ; \mathrm{pr}=0.000$ & & & \\
\hline
\end{tabular}


Table 6: Separate probit estimations of JIT and CAD/CAM adoption including adoption of the other technology as additional control

\begin{tabular}{|c|c|c|}
\hline & JIT adoption & CAD/CAM adoption \\
\hline \multicolumn{3}{|l|}{ Location characteristics } \\
\hline Large urban area dummy & $\begin{array}{l}-0.306^{* * *} \\
(0.118)\end{array}$ & $\begin{array}{l}0.303 * * * \\
(0.113)\end{array}$ \\
\hline Accessibility & $\begin{array}{l}0.008 * * * \\
(0.003)\end{array}$ & $\begin{array}{l}0.004 \\
(0.003)\end{array}$ \\
\hline \multicolumn{3}{|l|}{ Plant Characteristics } \\
\hline Size (number of employees) & $\begin{array}{l}0.001 * * * \\
(0.0004)\end{array}$ & $\begin{array}{l}0.001 * * * \\
(0.0004)\end{array}$ \\
\hline Skill & $\begin{array}{l}-0.001 \\
(0.018)\end{array}$ & $\begin{array}{l}0.062 * * * \\
(0.016)\end{array}$ \\
\hline Foreign ownership & $\begin{array}{l}0.603 * * * \\
(0.177)\end{array}$ & $\begin{array}{l}-0.373 \\
(0.205)\end{array}$ \\
\hline$\%$ of EU foreign capital & $\begin{array}{l}-0.006^{* * *} \\
(0.002)\end{array}$ & $\begin{array}{l}0.003 \\
(0.002)\end{array}$ \\
\hline $\begin{array}{l}\% \text { of sales in international } \\
\text { markets }\end{array}$ & $\begin{array}{l}0.002 \\
(0.0017)\end{array}$ & $\begin{array}{r}0.003 * * \\
(0.0016)\end{array}$ \\
\hline Small batch production & $\begin{array}{l}-0.198 * * \\
(0.098)\end{array}$ & $\begin{array}{l}0.145 \\
(0.101)\end{array}$ \\
\hline Outsourcing & $\begin{array}{l}0.122 \\
(0.116)\end{array}$ & $\begin{array}{l}0.432 * * * \\
(0.115)\end{array}$ \\
\hline Product innovation & $\begin{array}{l}0.301 * * * \\
(0.101)\end{array}$ & $\begin{array}{l}0.240^{* * *} \\
(0.109)\end{array}$ \\
\hline $\mathrm{CAD} / \mathrm{CAM}$ & $\begin{array}{l}0.412 * * * \\
(0.104)\end{array}$ & \\
\hline JIT & & $\begin{array}{l}0.437 * * * \\
(0.107)\end{array}$ \\
\hline No. of observations & 904 & 904 \\
\hline Log likelihood & -491.4 & -490.9 \\
\hline Pseudo $\mathrm{R}^{2}$ & 0.124 & 0.170 \\
\hline $\begin{array}{l}\text { Note: } * * * \text { denotes significance } \\
\text { corrected for clustering at the m } \\
\text { sector dummies. }\end{array}$ & $\begin{array}{l}\text { vel, } * * \text { the } 5 \\
\text { vel are repor }\end{array}$ & $\begin{array}{l}0 \% \text { level. Robust standard errors } \\
11 \text { estimations include } 22 \text { industry }\end{array}$ \\
\hline
\end{tabular}


Table 7: Bivariate probit estimations of JIT and CAD/CAM adoption

\begin{tabular}{|c|c|c|c|c|}
\hline \multirow{3}{*}{ Location characteristics } & \multicolumn{2}{|c|}{ (1) } & \multicolumn{2}{|c|}{ (2) } \\
\hline & \multirow[t]{2}{*}{ JIT } & \multirow[t]{2}{*}{ CAD/CAM } & \multirow[t]{2}{*}{ JIT } & \multirow[t]{2}{*}{ CAD/CAM } \\
\hline & & & & \\
\hline Large urban area dummy & $\begin{array}{l}-0.241 * * \\
(0.120)\end{array}$ & $\begin{array}{l}0.272 * * \\
(0.112)\end{array}$ & $\begin{array}{l}-0.272 * * \\
(0.113)\end{array}$ & $\begin{array}{l}0.264 * * \\
(0.109)\end{array}$ \\
\hline Accessibility & & & $\begin{array}{l}0.008 * * * \\
(0.003)\end{array}$ & $\begin{array}{c}0.005 \\
(0.003)\end{array}$ \\
\hline \multicolumn{5}{|l|}{ Plant Characteristics } \\
\hline Size (number of employees) & $\begin{array}{l}0.001 * * * \\
(0.0004)\end{array}$ & $\begin{array}{l}0.001 * * * \\
(0.0004)\end{array}$ & $\begin{array}{l}0.001 * * * \\
(0.0004)\end{array}$ & $\begin{array}{l}0.001 * * * \\
(0.0004)\end{array}$ \\
\hline Skill & $\begin{array}{c}0.004 \\
(0.018)\end{array}$ & $\begin{array}{l}0.060 * * * \\
(0.016)\end{array}$ & $\begin{array}{c}0.006 \\
(0.018)\end{array}$ & $\begin{array}{l}0.062 * * * \\
(0.017)\end{array}$ \\
\hline Foreign ownership & $\begin{array}{l}0.581 * * * \\
(0.170)\end{array}$ & $\begin{array}{l}-0.259 \\
(0.195)\end{array}$ & $\begin{array}{l}0.560 * * * \\
(0.171)\end{array}$ & $\begin{array}{l}-0.276 \\
(0.196)\end{array}$ \\
\hline$\%$ of EU foreign capital & $\begin{array}{l}-0.006 * * * \\
(0.002)\end{array}$ & $\begin{array}{c}0.002 \\
(0.002)\end{array}$ & $\begin{array}{l}-0.006 * * * \\
(0.002)\end{array}$ & $\begin{array}{c}0.002 \\
(0.002)\end{array}$ \\
\hline$\%$ of sales in international markets & $\begin{array}{c}0.002 \\
(0.0016)\end{array}$ & $\begin{array}{c}0.003 * * \\
(0.0016)\end{array}$ & $\begin{array}{c}0.002 \\
(0.0016)\end{array}$ & $\begin{array}{c}0.003 * * \\
(0.0015)\end{array}$ \\
\hline Small batch production & $\begin{array}{l}-0.153^{*} \\
(0.097)\end{array}$ & $\begin{array}{c}0.137 * \\
(0.099)\end{array}$ & $\begin{array}{l}-0.183^{* *} \\
(0.097)\end{array}$ & $\begin{array}{c}0.122 \\
(0.100)\end{array}$ \\
\hline Outsourcing & $\begin{array}{c}0.193 * \\
(0.111)\end{array}$ & $\begin{array}{l}0.456^{* * *} \\
(0.113)\end{array}$ & $\begin{array}{c}0.180 * \\
(0.112)\end{array}$ & $\begin{array}{l}0.448^{* * *} \\
(0.114)\end{array}$ \\
\hline Product innovation & $\begin{array}{l}0.339 * * * \\
(0.100)\end{array}$ & $\begin{array}{l}0.281 * * * \\
(0.106)\end{array}$ & $\begin{array}{l}0.331 * * * \\
(0.100)\end{array}$ & $\begin{array}{l}0.279 * * * \\
(0.106)\end{array}$ \\
\hline No. of observations & \multicolumn{2}{|c|}{904} & \multicolumn{2}{|c|}{904} \\
\hline Log likelihood & \multicolumn{2}{|c|}{-995.3} & \multicolumn{2}{|c|}{-989.7} \\
\hline Rho & \multicolumn{2}{|c|}{$0.258 * * *$} & \multicolumn{2}{|c|}{$0.257 * * *$} \\
\hline \multicolumn{5}{|c|}{$\begin{array}{l}\text { Note: } * * * \text { denotes significance at the } 1 \% \text { level, } * * \text { the } 5 \% \text { level, and } * \text { the } 10 \% \text { level. Robust standard errors } \\
\text { corrected for clustering at the municipality level are reported in parenthesis. All estimations include } 22 \text { industry } \\
\text { sector dummies. }\end{array}$} \\
\hline
\end{tabular}


Appendix A1. Survey variable description

\begin{tabular}{|c|c|c|c|}
\hline Name & Question & Measurement & Mean $^{(1)}$ \\
\hline JIT manufacturing & $\begin{array}{l}\text { Do you use JIT manufacturing } \\
\text { technology? }\end{array}$ & $\begin{array}{l}1=\text { Yes } \\
0=\text { No }\end{array}$ & 0.31 \\
\hline $\mathrm{CAD} / \mathrm{CAM}$ & $\begin{array}{l}\text { Do you use CAD/CAM production } \\
\text { technology? }\end{array}$ & $\begin{array}{l}1=\text { Yes } \\
0=\text { No }\end{array}$ & 0.65 \\
\hline Size & $\begin{array}{l}\text { No. of employees working in the } \\
\text { establishment. }\end{array}$ & No. of employees & 154.6 \\
\hline Skills & $\begin{array}{l}\text { Would you characterise the type of } \\
\text { work as technically complex? }\end{array}$ & $\begin{array}{l}\text { Respondents followed a Likert } \\
1-10 \text { scale, where } 1 \text { is "does } \\
\text { not reflect reality" and } 10 \text { is } \\
\text { "totally reflects reality" }\end{array}$ & 4.9 \\
\hline Foreign ownership & What is the origin of capital? & $\begin{array}{l}1=100 \% \text { Spanish } \\
0=\text { Otherwise }\end{array}$ & 0.24 \\
\hline $\begin{array}{l}\text { EU origin of foreign } \\
\text { capital }\end{array}$ & $\begin{array}{l}\text { What percentage of the capital has it's } \\
\text { origin in the European Union? }\end{array}$ & percentage & 15.7 \\
\hline $\begin{array}{l}\text { Sales in international } \\
\text { markets }\end{array}$ & $\begin{array}{l}\text { What percentage of sales has its } \\
\text { destination outside Spain? }\end{array}$ & percentage & 30.6 \\
\hline Small batch production $^{(2)}$ & Type of production & $\begin{array}{l}1=\text { small batch production } \\
0=\text { otherwise }\end{array}$ & 0.47 \\
\hline $\begin{array}{l}\text { Outsourcing in the } \\
\text { production process }\end{array}$ & $\begin{array}{l}\text { Have you outsourced production in the } \\
\text { last two years? }\end{array}$ & $\begin{array}{l}1=\text { Yes } \\
0=\text { No }\end{array}$ & 0.65 \\
\hline Product innovation & $\begin{array}{l}\text { Have you introduced technologically } \\
\text { new products over the last two years? }\end{array}$ & $\begin{array}{l}1=\text { Yes } \\
0=\text { No }\end{array}$ & 0.64 \\
\hline
\end{tabular}

Notes: (1) For dummy variables, the means reflects the percentage share of "Yes" answers among responding firms; (2) also includes manufacturing of single products by project. 


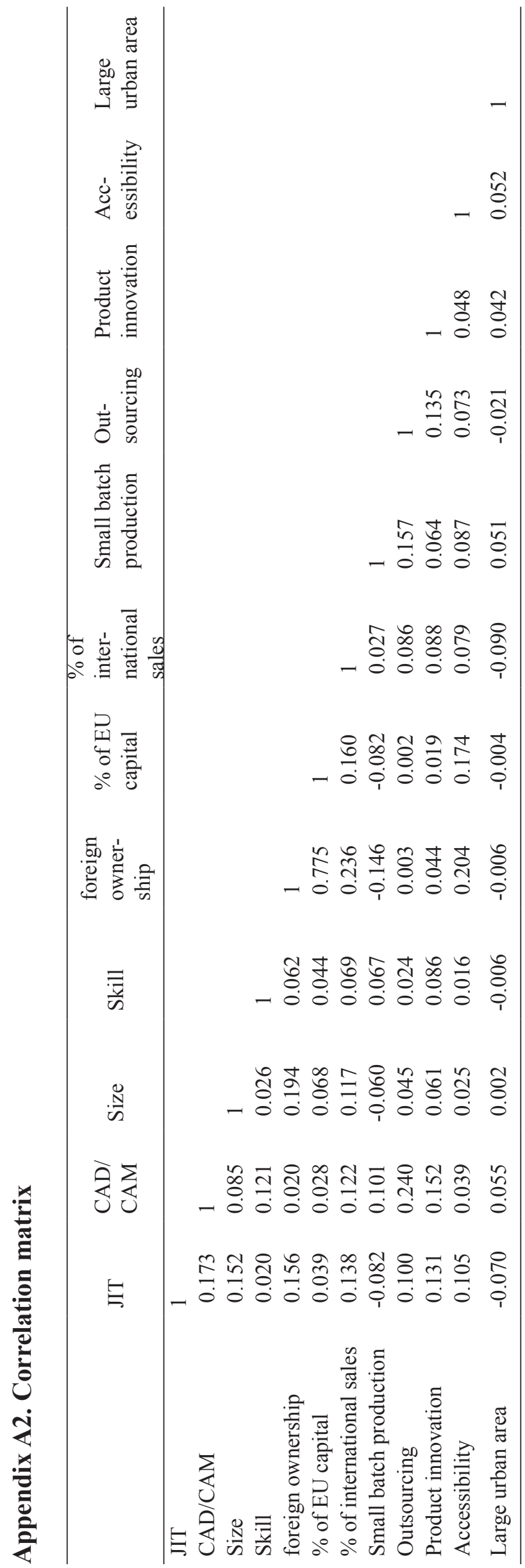


Working Papers published in:

Instituto de Políticas y Bienes Públicos (IPP), 2011

1. Holl, A., Pardo, R. \& Rama, R. Spatial patterns of adoption of just-in-time manufacturing. 